\title{
Potensi Pura Desa Pura Puseh Desa Pakraman Batuan Sebagai Daya Tarik Wisata Di Kabupaten Gianyar
}

Dwi Reni Mahaputri a,1, I Putu Anoma,2

1dwimahaputri10@yahoo.com,2putuanom@unud.ac.id

a Program Studi S1 Destinasi Pariwisata, Fakultas Pariwisata,Universitas Udayana, Jl. Dr. R. Goris, Denpasar, Bali 80232 Indonesia

\section{Abstract}

Potency of a tourist attraction is the most important things that can be pulled tourist visits. This research attempts to examine the potencies anything which is found in Desa Temple Puseh Temple Batuan Village. This research is expected could be referred to in the management of Desa Temple Puseh Temple Batuan Village can increase the time and the number of tourist visits. Informants in research were calculated by using the method the base informant and key informants. Technique data collection uses the observation, interview, and study literature. Data analysis technique used descriptive qualitative model Miles and Huberman.

The results of the research indicate that Desa Temple Puseh Temple Batuan Village as tourist attraction in Gianyar Regency not only have potencies of temple architecture and relic historical on occasion of the temple existence as one of cultural heritage, but also the tample have uniqueness potencie, such as art like dance, painting, and than a religious ceremony implemented in the temple area can be packaged to be a tourist product that can increase tourist visit durasion and can be beneficial for the Batuan Village community.

Keywords: Potencies, Tourism Attraction, Desa Temple Puseh Temple Batuan Village

\section{PENDAHULUAN}

Pura merupakan tempat beribadah bagi umat Hindu yang tersebar di setiap wilayah khususnya di Bali. Pura menjadi salah satu daya tarik wisata budaya bagi wisatawan baik wisatawan mancanegara maupun wisatawan nusantara.

Pura Desa Pura Puseh Desa Pakraman Batuan merupakan salah satu pura yang terdapat di Kabupaten Gianyar yang ramai dikunjungi wisatawan dengan jumlah kunjungan pada bulan Januari 2016 mencapai 5.193 wisatawan wisatawan (Buku Kunjungan Wisatawan, Januari 2016). Pura tersebut merupakan salah satu cagar budaya yang memiliki peninggalan bersejarah yang dilindungi dan tetap dilestarikan hingga saat ini.

Walaupun ramai dikunjungi wisatawan, tetapi waktu kunjungan wisatawan tergolong singkat dan cenderung menjadi daya tarik wisata transit karena lokasi pura yang strategis. Berkaitan dengan hal tersebut, tulisan ini diharapkan dapat memberikan hasil berupa pengklasifikasian potensi-potensi yang terdapat di area Pura Desa Pura Puseh Desa Pakraman Batuan yang dapat dikemas sebagai produk wisata yang nantinya berpengaruh terhadap jumlah dan durasi waktu kunjungan wisatawan serta berdampak positif terhadap sosial ekonomi masyarakat Batuan.

\section{TINJAUAN PUSTAKA}

Menutut Damarjati dalam Amirudin (2011) potensi obyek wisata adalah segala hal dan keadaan baik yang nyata dan dapat diraba, maupun tidak teraba, yang digarap, diatur, dan disediakan sedemikian rupa sehingga dapat bermanfaat atau dimanfaatkan atau diwujudkan sebagai kemampuan, faktor dan unsur yang diperlakukan atau menentukan bagi usaha dan pengembangan kepariwisataan, baik itu berupa suasana, kejadian, benda maupun layanan atau jasa-jasa. Potensi yang dimaksud dalam penelitian ini adalah potensi wisata baik potensi fisik maupun potensi non fisik yang ada di area pura dan dapat dijadikan sebagai baya tarik wisata bagi wisatawan yang mengunjungi Pura Desa Pura Puseh Desa Pakraman Batuan.

Istilah Pura sebagai tempat pemujaan umat Hindu berasal dari bahasa Sansekerta yang artinya kota atau benteng, kemudian berubah menjadi tempat pemujaan Hyang Widhi (Tuhan Yang Maha Esa) (Parisada Hindu Dharma Indonesia, 2013).

Dari berbagai jenis pura di Bali dengan pengertian sebagai tempat suci untuk memuja Tuhan (Sang Hyang Widhi Wasa) dan Manifestasi-Nya (Bhattara), dapat dikelompokan berdasarkan karakter atau sifat kekhasannya, dibagi ke dalam beberapa kelompok beberapa kelompok, yakni: dalam Titib (2003).

1. Pura Umum yang merupakan pura sebagai tempat pemujaan Hyang Widhi dengan segala manifestasi-Nya (Dewa). 
2. Pura Teritorial yang merupakan tempat pemujaan dari anggota masyarakat dalam wilayah desa adat, yakni Pura Kahyangan Tiga yaitu Pura Desa, Pura Puseh, Pura Dalem sebagai tempat memuja Hyang Widhi dalam manifestasinya.

3. Pura Fungsional yang merupakan pura dengan karakter khusus, yang berkaitan dengan sistem mata pencaharian hidup.

4. Pura Kawitan yang merupakan Pura yang dilandasi oleh ikatan wit atau leluhur berdasarkan garis kelahiran (genealogis).

Menurut Undang-Undang Republik Indonesia Nomor 10 Tahun 2009 tentang Kepariwisataan yang dimaksud daya tarik wisata adalah segala sesuatu yang memiliki keunikan, keindahan, dan nilai yang berupa keanekaragaman kekayaan alam, budaya, dan hasil buatan manusia yang menjadi sasaran atau tujuan kunjungan wisatawan.

Berdasarkan definisi tersebut dapat didefinisikan bahwa daya tarik wisata merupakan faktor penarik minat kunjungan wisatawan yang berkaitan dengan keunikan dan keistimewaan yang terdapat pada suatu kawasan pariwisata. Adapun beberapa jenis daya tarik wisata, antara lain:

1. Daya Tarik Wisata Alam

Daya tarik wisata alam adalah sumber daya alam yang berpotensi serta memiliki daya tarik bagi pengunjung baik dalam keadaan alami maupun setelah ada usaha budidaya.

\section{Daya Tarik Wisata Budaya}

Daya tarik wisata budaya merupakan hasil ciptaan manusia berupa benda-benda bersejarah, kebudayaan atau sistem keagamaan. Adapun 10 elemen budaya yang dapat dimanfaatkan dan dikembangkan sebagai daya tarik wisata menurut Shaw dan Williams dalam Ardika (2007), antara lain: (1) kerajinan, (2) arsitektur, (3) sejarah dari suatu tempat atau daerah, (4) tradisi, (5) makanan lokal atau tradisional, (6) seni dan musik, (7) cara hidup suatu masyarakat, (8) bahasa, (9) agama, (10) pakaian lokal atau pakaian tradisional.

3. Daya Tarik Wisata Buatan Manusia

Daya tarik wisata buatan manusia merupakan daya tarik wisata khusus yang merupakan daya tarik kreasi artifisial (artificially created) serta kegiatan-kegiatan manusia lainnya di luar dari wisata alam dan wisata budaya.

Pura Desa Pura Puseh Desa Pakraman Batuan merupakan Pura Kahyangan Tiga yang menjadi daya tarik wisata budaya di Kabupaten Gianyar yang memiliki potensi wisata yang mempengaruhi kunjungan wisatawan, baik wisatawan lokal maupun wisatawan asing.

\section{METODE PENELITIAN}

Lokasi penelitian yakni di Pura Desa Pura Puseh Desa Pakraman Batuan yang memiliki luas area pura 100 are, terdiri dari tiga bagian yakni: Mandala Jaba, Mandala Jaba Tengah dan Jaba Jeroan Pura tersebut terletak di Dusun Tengah, Desa Pakraman Batuan, Kecamatan Sukawati, Gianyar. Potensi wisata yang dibahas dalam penelitian ini adalah potensi wisata yang terdapat di area Pura Desa Pura Puseh Desa Pakraman Batuan.

Metode pengumpulan data yang dilakukan adalah dengan observasi, wawancara, dan dokumentasi. Observasi yang dilakukan mengetahui kondisi langsung pada lokasi penelitian serta melengkapi hasil temuan di lapangan. Wawancara dilakukan dengan Bendesa Desa Pakraman Batuan serta dengan orang-orang yang disarankan oleh Bendesa Desa Pakraman Batuan untuk memberikan informasi mengenai gambaran umum lokasi penelitian dan potensi yang terdapat di Pura Desa Pura Puseh Desa Pakraman Batuan sebagai daya tarik wisata.

Dalam menentukan informan digunakan teknik penentuan informan pangkal dan informan kunci. yang telah terkumpul mengenai potensi Pura Desa Pura Puseh Desa Pakraman Batuan dianalisis menggunakan analisis data kualitatif model Miles dan Hubberman, yaitu analisis data kualitatif yang dilakukan secara interaktif dan berlangsung terus menerus hingga tuntas, sehingga data data yang diperoleh mencapai jenuh, yang ditandai dengan tidak diperoleh data atau informasi baru terkait dengan masalah penelitian. Adapun kegiatan yang berkaitan dengan analisis data model tersebut, antara lain: kegiatan reduksi data (data reduction), penyajian data (data display), serta penarikan kesimpulan dan verifikasi data (conclusion drawing and verification) (Sugiyono, 2010). 


\section{HASIL DAN PEMBAHASAN}

Potensi fisik Pura Desa Pura Puseh Desa Pakraman Batuan menjadi salah satu daya tarik yang dapat dilihat secara langsung oleh wisatawan yang berkunjung. Adapun potensi fisik tersebut, meliputi:

1. Arsitektur Pura

Arsitektur pada Pura Desa Pura Puseh Desa Pakraman Batuan berbeda dengan Pura Puseh Pura Desa yang terdapat di Bali pada umumnya, terdapat beberapa bangunanbangunan suci atau palinggih yang jarang ada di area Pura Puseh Pura Desa pada umumnya juga menjadi daya tarik tersendiri. Arsitektur pura juga berkaitan dengan Landscape pura yang diatur sedemikian rupa sejak adanya Pura Desa Pura Puseh Desa Pakraman Batuan tersebut, dan sampai saat ini tetap dijaga kerapiannya sehingga mendukung kegiatan pariwisata di pura tersebut. Landscape Pura berkaitan dengan posisi setiap palinggih, penataan bale-bale pendukung kegiatan keagamaan serta penataan taman yang ada di area pura.

Pura Desa Pura Puseh Desa Pakraman Batuan memiliki luas 100 are yang terdiri dari Mandala Jaba seluas 25 are dan Mandala Jaba Tengah serta Jaba Jeroan seluas 75 are. Pembagian halama ataua Mandala di pura tersebut dibagi menjadi tiga mandala (Aniek dan Tenaya, 2009), antara lain:

\section{a. Mandala Jaba}

Bagian ini merupakan sisi terluar yang berada pada sisi selatan dari kompleks Pura Desa Pura Puseh Desa Pakraman Batuan yang terdapat jalan raya. Di selatan jalan raya terdapat sebuah wantilan, Palinggih Tumpek, dan beberapa bangunan pendukung kegiatan pariwisata, seperti: kios, toilet dan terdapat Kantor Lembaga Perkreditan Desa (LPD).

\section{b. Mandala Jaba Tengah}

Pada bagian mandala Jaba Tengah terdapat bale kulkul yang terletak di sudut tenggara Bale Agung. Selain itu juga terdapat Bale Penyimpenan Gong/ Pengambuhan, Pendeman Bagia, Palinggih Balang Tamak dan dua Apit Lawang. Sebelum memasuki Kori Agung menuju Mandala Jeroan terdapat dua buah pura yang dikelilingi oleh tembok pelindung, yakni sebelah kiri atau sebelah Barat merupakan Pura Pengulun Desa dan sebelah kanan atau sebelah Timur merupakan Pura Maksan Budamanis.

\section{c. Mandala Jeroan}

Pada halaman Jerooan terdapat beberapa palinggih dan bangunan, antara lain: Palinggih Gedong Sari (Tumpang 2), Palinggih Peliangan, Palinggih Gedong Tarib, Palinggih Taksu, Palinggih Ngerura, Palinggih Ida Ratu Saun, Palinggih Ida Ratu Atma, Palinggih Sanghyang Basuki, Palinggih Padmasana, Palinggih Meru Tumpang, Meru Kehen Tumpang 3, Palinggih Pingkupan, Palinggih Ida Ratu Pande, Palinggih Ida Ratu Selimpet, Bale Peselang, Bale Agung, Bale Sakapat, Palinggih Ida Bagawan Penyarikan, Gedong Ngurah Bumi, Pesimpenan Ratu Batur,Bale Tiang Sanga, Bale Penetegan, Pengiasan Agung, Pengaeuman, Bale Penyimpenan Gong/ Pegambuhan, Bale Gong, Bale Semar Pegulingan/ Pesantian, Bale Kulkul, Arip-Arip, Perantenan Suci, Pesimpenan Ratu Batukaru,Palinggih Balang Tamak, Apit Lawang, Pendeman Bagia, Bale Pesanekan, Pengaruman, Padmasari, Gedong Penyimpenan, Piyasan, Palinggih Ratu Alit, dan Bale Perantenan.

\section{Peninggalan Bersejarah}

Pura Desa Pura Puseh Desa Pakraman Batuan sebagai salah satu Cagar Budaya di Kabupaten Gianyar memiliki peninggalanpeninggalan bersejarah yang berupa Lingga, Arca, serta benda peninggalan lainnya. Peninggalan bersejarah tersebut tidak hanya ditata pada Balai Bersejarah yang terletak di sebelah utara pura tetapi juga diletakkan di beberapa Palinggih atau bangunan suci yang ada di bagian Mandala Jeroan pura tersebut, meliputi:

a. Bangunan Suci/ Palinggih Ida Ratu Selimpet Pada Palinggih Ida Ratu Selimpet terdapat satu buah Arca yang disebut Arca Garuda. Arca tersebut merupakan arca yang memiliki dua sisi, yakni sisi barat dan sisi timur. Kedua bagian sisi tersebut memiliki ciriciri yang sama, yakni arca berada dalam posisi menjongkok, menggunakan mahkota yang berbentuk jamahkota. Selain itu pada arca tersebut terdapat prabhamandala yang berbentuk bulat ke atas yang saat ini dalam keadaan pecah, dengan kedua tangan yang diangkat ke bagian atas di sebelah telinga Arca Garuda.

b. Bangunan Suci Gedong Kehen

Peninggalan bersejarah yang terdapat pada bangunan Gedong Kehen, antara lain: terdapat satu Fragmen Kepala Arca, dua buah Arca Perwujudan Bethari, tiga buah Arca 
Perwujudan Bethara, dua buah Kotak Perimpih, satu Fragmen Bangunan atau Kemuncak, satu buah Mudra (Bagian puncak dari suatu bangunan), satu buah Fragmen Lingga, empat buah Fragmen Arca, dan satu buah Lingga.

c. Bangunan Suci atau Palinggih Apit Lawang

Palinggih Apit Lawing terdiri dari dua buah Palinggih yang terdapat di sebelah timur Pura Desa Pura Puseh Desa Pakraman Batuan. Kedua Palinggih Apit Lawang memiliki Arca yang berbeda satu sama lainnya, yakni pada Palinggih Apit Lawang sebelah kiri atau bagian utara terdapat Arca Dwarapala (arca dalam posisi duduk) dengan tinggi $63 \mathrm{~cm}$, lebar 37 $\mathrm{cm}$, dan tebal $38 \mathrm{~cm}$, dimana kondisi arca tersebut pada bagian wajah tidak begitu jelas karena sudah dalam keadaan patah dan pecah. Sedangkan Palinggih Apit Lawang sebelah kanan atau bagian selatan terdapat Arca Buddha dengan tinggi $71 \mathrm{~cm}$, lebar $39 \mathrm{~cm}$ dan tebal $55 \mathrm{~cm}$ dan dalam kondisi yang sudah patah dan pecah.

d. Bangunan Suci atau Palinggih Ida Ratu Pande

Bangunan Palinggih Ida Ratu Pande menjadi tempat pemujaan untuk memohon kepintaran atau kepandaian. Pada Palinggih tersebut terdapat sepasang Relief Kinara dan Kinari, satu buah Arca Perwujudan Bethari, satu buah Arca memegang ayam, dua buah Fragmen Arca satu buah Fragmen Arca Perwujudan, dan satu buah Fragmen Lapik.

e. Bangunan Suci/ Palinggih Ida Ratu Saung

Pada Palinggih Ida Ratu Saung terdapat beberapa peninggalan bersejarah yakni sepasang Relief Kinara-Kinari dengan ukuran masing-masing, yakni Kinara dengan tinggi 46 $\mathrm{cm}$, lebar $15 \mathrm{~cm}$ dan tebal $33 \mathrm{~cm}$ serta Kinari dengan tinggi $45 \mathrm{~cm}$, lebar $16 \mathrm{~cm}$ dan tebal 31 $\mathrm{cm}$, Arca Dwarapala dengan tinggi $51 \mathrm{~cm}$, lebar $22 \mathrm{~cm}$ dan tebal $28 \mathrm{~cm}$, Arca Perwujudan Bethari dengan tinggi $66 \mathrm{~cm}$, lebar $20 \mathrm{~cm}$ dan tebal $26 \mathrm{~cm}$, serta Fragmen Arca dengan tinggi $36 \mathrm{~cm}$, lebar $26 \mathrm{~cm}$ dan tebal $30 \mathrm{~cm}$.

Selain itu pada Palinggih Ida Ratu Saung juga terdapat Arca Membawa Ayam yang memiliki ukuran yakni tinggi $42 \mathrm{~cm}$, lebar 29 $\mathrm{cm}$ dan tebal $23 \mathrm{~cm}$. Keberadaan arca tersebut mimiliki kaitan dengan pelaksanaan tradisi Sabung Ayam atau megocekan yang dilaksanakan setiap tahunnya dari sasih kelima hingga sasih kasanga atau pada Bulan
November sampai awal Bulan Maret yang berlangsung pada sore hari.

f. Palinggih Sedahan Penyarikan

Pada Palinggih Sedahan Penyarikan terdapat satu buah Lingga yang difungsikan sebagai media pemujaan dengan tinggi $58 \mathrm{~cm}$, lebar $20 \mathrm{~cm}$, tebal $20 \mathrm{~cm}$ dan diameter $19 \mathrm{~cm}$ yang memiliki tiga bagian, yakni Siwabhaga yang merupakan bagian berbentuk bulatan, Wisnubhaga yang merupakan bagian dengan segi delapan, serta Brahmabhaga yang merupakan bagian segi empat. Keadaan Lingga tersebut masih utuh hanya saja terdapat sedikit kerusakan pada beberapa bagian.

g. Gapura Kuno

Gapura Kuno terdapat di bagian barat yang menjadi salah satu pintu masuk Pura Desa Pura Puseh Desa Pakraman Batuan dengan ukuran tinggi 12,11 meter, lebar 5,26 meter dan tebal 3,54 meter terbuat dari batu padas yang memiliki keunikan dari segi sejarah gapura yang merupakan peninggalan pada zaman Kebo Iwa, dimana beliau yang membuat ukiran dari gapura dengan menggunakan kuku jari, segi fungsi gapura berkaitan dengan kepercayaan masyarakat sebagai tempat atau jalur keluar masuknya para Dewa Dewi yang diundang saat dilaksanakannya kegiatan upacara atau piodalan untuk menyaksikan kegiatan upacara yang berlangsung, dari segi bentuk gapura yang masih dilestarikan dan dijaga seperti bentuk aslinya walaupun pernah dilakukan pemugaran, dan keunikan dari segi struktur gapura yang masih menggunakan bagian-bagian yang utuh dari gapura saat dilakukan pemugaran

Selain potensi tersebut, Pura Desa Pura Puseh Desa Pakraman Batuan memiliki potensi-potensi yang dapat dikelola sebagai daya tarik wisata sehingga dapat meningkatkan jumlah kunjungan wisatawan serta menjadikan pura tersebut tidak hanya sebagai daya tarik wisata transit di Kabupaten Gianyar, antara lain:

1. Kesenian

Potensi Pura Desa Pura Puseh Desa Pakraman Batuan yang berkaitan dengan kesenian, antara lain:

a. Tari Rejang Sutri

Tari Rejang Sutri merupakan tari Wali (sakral) yang dipentaskan pada saat pelaksanaan upacara Dewa Yadnya atau 
Upacara Keagamaan yang berlangsung di area Pura Desa Pura Puseh Desa Pakraman Batuan. Pelaksanaan Tari Rejang Sutri yakni akhir sasih kelima sampai sasih kesanga atau pada Bulan November sampai dengan Bulan Maret yang dilaksanakan pada pukul 19.00 WITA. Pelaksanaan Tari Rejang Sutri berkaitan dengan kepercayaan masyarakat terhadap gangguan dari I Gede Mecaling untuk membalas dendam atas kekalahan melawan I Dewa Babi yang tinggal di Desa Batuan, serta kepercayaan masyarakat di Bali pada umumnya tehadap timbulnya bermacammacam penyakit pada sasih tersebut.

Berkaitan dengan pelaksanaan Tari Rejang Sutri, ditarikan oleh perempuan dari masing-masing banjar di Desa Batuan yang tidak dalam keadaan cuntaka dan tidak dibatasi oleh usia yang diwajibkan untuk ngayah atau secara sukarela ikut berpartisipasi dalam pelaksanaan tari tersebut. Iringan yang digunakan saat pementasan Tari Rejang Sutri yakni lagu-lagu yang berkaitan dengan Legong Lasem, Pelayon, dan Kuntul, dengan menggunakan instrument, seperti: kemong, kendang, kepul, kajar, ceng-ceng, gangsa pengugal, pemade, kantil, jublag, dan jegogan. Busana yang digunakan saat pementasan tari Rejang Sutri dibedakan menjadi dua berdasarkan hari pelaksanaannya. Busana pada hari-hari biasa, atau tidak bertepatan dengan rahinan, penari Tari Rejang Sutri menggunakan kebaya atau busana seperti busana ke pura. Sedangkan pada hari-hari yang bertepatan dengan rerahinan, penari tersebut menggunakan busana menari seperti penggunaan tapih dan selendang yang berbahan kain prada atau lainnya dengan hiasan kepala menggunakan antol, bunga emas, bunga sandat dan cempaka serta wajah yang dirias dengan riasan tari.

\section{b. Tari Gambuh}

Tari Gambuh tergolong ke dalam jenis tari bebali yang memiliki dua fungsi antara lain sebagai tari sacral dalam upacara keagamaan tertentu dan sebagai tari hiburan. Keberadaan Tari Gambuh di Desa Batuan pada tahun dua puluhan dipentaskan pada saat pelaksanaan Wali atau kegiatan upacara keagamaan di Pura Desa Pura Puseh Desa Pakraman Batuan yang diatur oleh kaum Wangsa Brahmana Budha yang ada di Desa Batuan. Pertunjukan Tari Gambuh di Desa Batuan tidak hanya pada saat kegiatan keagamaan tetapi pernah dikemas sebagai salah satu produk wisata yang dilaksanakan pada tanggal 15 setiap bulan dan pada tahun 2014 pertunjukan tersebut divakumkan sementara. Pementasan Tari Gambuh tidak terlepas dari adanya ceritacerita rakyat yang diangkat sebagai cerita dalam pementasan tari tersebut seperti: cerita punalas tratebang, cerita kesandung lasem, dedoyan dan cerita terbunuhnya kuda $\mathrm{Ki}$ Dalang Anteban. Jumlah penari yang ikut serta dalam pementasan Tari Gambuh disesuaikan dengan cerita yang dibawakan, dimana secara umum jumlah penari dan penabuh pada satu pertunjukan yakni sebanyak 45 orang.

Pertunjukan Tari Gambuh tidak terlepas dari adanya iringan musik yang disebut dengan gambelan Gambuh, dimana gambelan tersebut termasuk ke dalam gambelan madya atau gambelan yang bersifat gending-gendingan. Keunikan pada gambelan tersebut terdapat pada instrument gambelan yang menggunakan suling sebagai salah satu alat musih khas dari gambelan Gambuh yang berukuran besar berkisar $75 \mathrm{~cm}$ sampai $100 \mathrm{~cm}$. Selain musik suling, juga digunakan beberapa instrumen lain, seperti: kangsi, gumanak, rincik, gentorag, kenyir dan klenang (Mangku Bawa, wawancara tanggal 13 April 2016).

\section{c. Tari Genggong}

Tari Genggong tergolong ke dalam jenis tari bali-balihan atau tari hiburan yang menggunakan cerita tentang Pangeran Jenggala yang berburu, kemudian dipastu menjadi seekor kodok sampai akhirnya kembali menjadi pangeran (Wirtawan, wawancara tanggal 15 April 2016). Tari Genggong merupakan salah satu tari khas yang terdapat di Desa Batuan yang biasanya dipertunjukan ke hotel-hotel dan belum dikemas sebagai salah satu produk yang menjadi penarik kunjungan wisatawan pada Pura Desa Pura Puseh Desa Pakraman Batuan.

Adapun keunikan dari tari Genggong terletak pada musik pengiringnya, yakni musik Genggong yang merupakan alat musik instrumental tradisional yang lebih awal muncul sebelum adanya Tari Genggong. Alat musik Genggong dimaikan dengan menggunakan nafas bukan ditiup seperti memainkan alat musik suling sehingga tidak semua orang dapat memainkan alat musik tersebut. Alat musik Genggong sebagai 
pengiring tarian ditambahkan dengan beberapa alat musik lainnya, seperti: kendang, rentid, ceng-ceng, suling, dan tawa-tawa yang akhirnya menjadi alat musik yang utuh yang bisa memainkan beberapa lagu dengan menggunakan laras selendro yang memiliki empat nada pokok, yakni: ndang, nding, ndung, dan ndeng yang memiliki kesamaan dengan laras angklung. Hal tersebut membuat kesenian Genggong Desa Batuan mengambil beberapa bentuk gending angklung yang sampai saat ini masih dimaikan, yaitu: Tabuh Telu, Tabuh Angklung Kuta, Sekar Saridat, Elag Elog, Konokan Ngoyong, Sekar Sungsang, Tabuh Angklung Dentiyis, Gegineman, Tangis, Konokan Mejalan, Janger, dan Dongkang Menek Hiu (Artha, wawancara tanggal 17 April 2016).

d. Lukisan pada Wantilan Pura

Keberadaan lukisan-lukisan di area Pura Desa Pura Puseh Desa Pakraman Batuan tepatnya yang diletakkan pada wantilan pura dengan jumlah lukisan yakni 48 lukisan bergaya lukisan Batuan yang merupakan hasil dari 40 pelukis Desa Batuan. Pembuatan lukisan tersebut dilakukan secara swadaya yang pengerjaannya diselesaikan tahun 2013 dengan mengangkat cerita kehidupan masyarakat Desa Pakraman Batuan yang berkaitan dengan kegiatan keseharian masyarakat, kesenian yang ada di Desa Batuan, kegiatan keagamaan yang dilaksanakan serta berkaitan dengan keberadaan Pura Desa Pura Puseh Desa Pakraman Batuan serta terdapat delapan lukisan berupa lukisan pewayangan (Wastika, wawancara tanggal 4 April 2016).

Keberadaan lukisan-lukisan tersebut dapat dijadikan penunjang Pura Desa Pura Puseh Desa Pakraman Batuan sebagai daya tarik wisata dengan menambahkan deskripsi atau keterangan dari masing-masing lukisan yang dipajang cerita-cerita yang terkandung di dalam lukisan tersebut dapat tersampaikan kepada wisatawan yang berkunjung.

\section{Upacara Keagamaan}

Kegiatan upacara keagamaan dapat dijadikan sebagai suatu daya tarik bagi wisatawan yang berkunjung ke Pura Desa Pura Puseh Desa Pakraman Batuan, dimana wisatawan dapat menyaksikan secara langsung kegiatan upacara tersebut. Adapun upacara keagamaan yang dilaksanakan di pura tersebut, antara lain: a. Upacara Wali Senjata yang dilaksanakan pada Saniscara Kliwon Wuku Landep.

b. Upacara Wali Ratu Desa yang dilaksanakan pada Buda Kliwon Wuku Gumbreg.

c. Upacara Wali Ratu Puseh yang dilaksanakan pada Saniscara Kliwon Wuku Gumbreg

d. Upacara Wali yang jatuh pada Saniscara Kliwon Wuku Wariga (Tumpek Wariga) yang dilaksanakan 6 bulan sekali.

e. Upacara Wali atau Petirtan (Ngusaba Pura) jatuh pada Saniscara Kliwon Wuku Wariga (Tumpek Wariga) yang dilaksanakan satu tahun sekali.

f. Upacara Wali Ratu Tupeng yang dilaksanakan setian Saniscara Kliwon Wuku Wayang.

g. Upacara Wali Ratu Rambut Sedana yang dilaksanakan pada Buda Cemeng Wuku Klawu.

h. Upacara Wali Bhatara Sri yang dilaksakana setiap Sukra Umanis.

i. Upacara Wali Ida Sang Hyang Aji Saraswati yang dilaksanakan pada Saniscara Umanis Wuku Watugunung (Mangku Suda, wawancara 7 April 2016).

Upacara-upacara keagamaan tersebut dapat menjadi daya tarik bagi wisatawan apabila dipromosikan kepada wisatawan sehingga wisatawan mengetahui waktu pelaksanaan upacara tersebut dan wisatawan dapat berkunjung bertepatan dengan berlangsungnya kegiatan keagamaan di pura tersebut.

\section{SIMPULAN DAN SARAN}

\section{Simpulan}

Potensi Pura Desa Pura Puseh Desa Pakraman Batuan, antara lain: arsitektur pura, peninggalan bersejarah, kesenian dan upacara keagamaan. Potensi pura yang dapat dilihat secara langsung oleh wisatawan adalah arsitektur dan peninggalan bersejarah yang ditempatkan pada balai bersejarah dan beberapa pelinggih yang terdapat di area pura. Dari potensi-potensi yang terdapat di area pura, ada beberapa potensi yang harus dikelola lebih baik lagi untuk menunjang keberadaan pura sebagai daya tarik wisata, yakni pelaksanaan Tari Rejang Sutri yang jarang diketahui oleh wisatawan karena waktu pelaksanaannya yakni malam hari, keberadaan Tari Gambuh sebagai salah satu produk wisata yang tidak dijalankan 
sementara waktu dan Tari Genggong sebagai tari khas Desa Batuan yang saat ini belum dijadikan sebagai produk wisata yang dapat disaksikan oleh wisatawan. Selain itu juga, keberadaan lukisan pada wantilan pura tidak hanya sebagai pajangan tetapi juga menjadi daya tarik bagi wisatawan yang berkunjung, dimana lukisanlukisan tersebut menceritakan kehidupan masyarakat Desa Batuan serta Pura Desa Pura Puseh Desa Pakraman Batuan.

\section{Saran}

Perlu disediakan papan informasi yang berisi keterangan mengenai peninggalanpeninggalan bersejarah yang dapat membantu wisatawan untuk mengetahui klasifikasi peninggalan-peninggalan bersejarah yang diletakkan pada Balai Purbakala atau yang terdapat pada beberapa palinggih di area pura serta papan informasi mengenai lukisan-lukisan yang terdapat di wantilan pura, sehingga wisatawan dapat mengetahui cerita dibalik lukisan tersebut. Pengelolaan pura sebagai daya tarik wisata tidak boleh lepas dari adanya partisipasi masyarakat lokal, hal ini dapat direalisasikan oleh pihak pengelola agar disiapkannya pemandu wisata lokal yang bertugas untuk menemani wisatawan saat mengelilingi area pura dan memberikan penjelasan mengenai keberadaan pura berkaitan dengan sejarah pura serta klasifikasi peninggalan bersejarah, sehingga wisatawan memperoleh pengetahuan dan wawasan mengenai keberadaan pura sebagai cagar budaya di Kabupaten Gianyar. Potensi berupa kesenian dapat dikemas sebagai daya tarik untuk menunjang keberadaan Pura Desa Pura Puseh Desa Pakraman Batuan dengan membuat suatu manajemen pengelola yang bertugas untuk merencanakan pengemasan kesenian sebagai produk wisata dan melakukan pengorganisasian sumber daya manusia dalam hal ini keterlibatan masyarakat lokal sehingga pelestarian terhadap kesenian khas Desa Batuan berjalan selaras dengan peningkatan sektor perekonomian masyarakat lokal.

Daftar Pustaka:

Amirudin A., Faris. 2011. Kajian Potensi Wisata Ketep Pass Dalam Analisis Spasial. Skripsi: Fakultas Keguruan dan Ilmu Pendidikan Universitas Sebelas Maret.

Ardika, I Wayan. 2007. Pusaka Budaya dan Pariwisata. Denpasar: Pustaka Larasan.

Bendesa Desa Pakraman Batuan. 2016. Data Kunjungan Wisatawan ke Pura Puseh/ Desa di Desa Batuan pada Bulan Januari 2016. Gianyar: Bendesa Desa Pakraman Batuan.

Parisada Hindu Dharma Indonesia. 2013. Swastikarana, Pedoman Ajaran Hindu Dharma. Denpasar: PT. Mabhakti.

Perda. 2009. Perda Provinsi Bali Nomor 16 Tahun 2009 pasal 1 ayat 57 tentang Rencana Tata Ruang Wilayah Provinsi Bali Tahun 2009-2029. Bali: Pemerintah Provinsi Bali.

Purniti, Aniek dan Yadnya Tenaya. 2009. Inventarisasi dan Penetapan Benda Cagar Budaya/ Situs Di Pura Puseh Desa Batuan Kecamatan Sukawati Kabupaten Gianyar. Bali: Balai Pelestarian Peninggalan Purbakala.

Sugiyono. 2010. Metode Penelitian Pendidikan Pendekatan Kuantitatif, Kualitatif, dan R\&D. Bandung: Alfabeta.

Titib, I Made. 2003. Teologi \& Simbol-Simbol Dalam Agama Hindu. Surabaya: Paramita. 